The $B D J$ News section accepts items that include general news, latest research and diary events that interest our readers. Press releases or articles may be edited, and should include a colour photograph if possible. Please direct your correspondence to the News Editor, Arveen Bajaj at the $B D J$, The Macmillan Building, 4 Crinan Street, London N19XW or by email to bdj@bda.org

\section{DCP health checks}

Dental care professionals (DCPs) registering with the General Dental Council (GDC) will be able to ask either their employing or supervising dentist or a doctor to sign their health certificate, following changes made by the Council.

Dental technicians and dental nurses who do not work in a clinical environment will need to make a selfdeclaration about their health and confirm they do not have any clinical contact with patients.

The GDC says the registration application process enables it to assess an applicant's fitness to carry out their professional duties - DCPs applying for registration need to provide certain information about their professional training, character and health. The changes are in recognition of the fact that some roles are more exposureprone than others and therefore carry different degrees of risk for patients.

Applicants who may have already paid for medical examinations as part of the application process, who would not require them under the new guidance, will be eligible to apply to the GDC for a refund. For more information visit www.gdc-uk.org/Potential+registrant/ or call 02078873800 .

\section{Smiles all round}

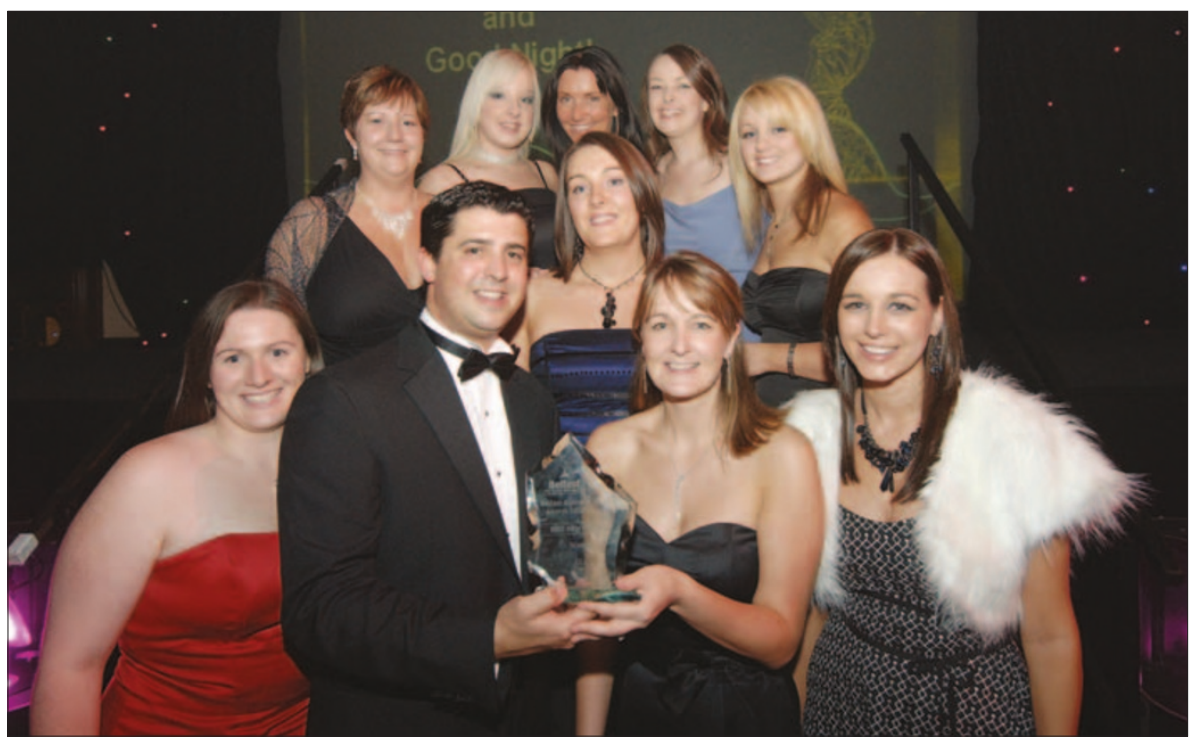

Dunmurry Dental Practice has won an award at the prestigious Belfast Business Gala Awards ceremony which took place in the City Hall recently. The award was given to the company that 'displayed a strategic approach to business, successful implementation and has good prospects for the future'.

Philip McLorinan, Prinicipal Dentist and Owner said, "I was surprised but delighted to win the award, however the team have worked exceptionally hard to deliver a high quality service and to build the new business".

Since Dunmurry Dental Practice opened two years ago, the emphasis on patient satisfaction has been evident throughout the service, and has resulted in the practice winning three other awards since opening: finalist in Lisburn City Business Awards 2004, New Business Marketing Award (CIM-All Ireland) 2005 and Highly Commended in the Dental Awards - Practice Marketing 2006. The Practice has also been nominated as Best Practice in the UK Dentistry Awards to be held later this year.

Pictured above, Philip McLorinan, with Debbie McLorinan, Paula McCarthy, Tracey Campbell, Debbie McKinney, Sharon Boyle, Denise Campbell, Cathy Smith, Maria Nolan and Joanne Jenkins.

\title{
GDC prosecutes non-dentist over tooth whitening
}

The General Dental Council (GDC) has challenged in court for the first time the practice of non-dentists offering toothwhitening treatments. The GDC brought a case of alleged "illegal practice of dentistry" against Ben Nahab, who pleaded guilty. He had performed a tooth whitening procedure in May 2006. Mr Nahab was convicted, and ordered to pay a fine plus costs and compensation.
The case was heard at Norwich Magistrates Court on 26 October. The GDC is seeking a landmark ruling so that it can stamp out the practice by non-dentists. Dental professionals have contacted the GDC expressing concerns about the safety of non-dentists offering such a service.

GDC President Hew Mathewson said, "The General Dental Council's priority is to protect the public. Tooth whitening can be dangerous, particularly in the hands of unregistered professionals. We believe that, for public safety, only registered dentists should be permitted to carry out tooth whitening procedures or provide clinical advice about such treatments. If we receive information that suggests an unregistered person may be practising dentistry illegally, we will investigate." 


\section{New target for treating craniofacial pain}

A new study, published in the Journal of Neurochemistry, identifies a key interaction between head and neck nerve cell proteins that may help shed light on migraines and temporomandibular joint disorders

Researchers at Oregon Health \& Science University's School of Dentistry have uncovered an interaction between two proteins in the nerve cells that carry pain information from the head and neck to the brain.

They claim that the finding could play a significant role in the development of therapies to cure migraines and other craniofacial pain conditions like TMJ (temporomandibular joint) disorder.

"Our discovery reveals the complexities of pain signalling mechanisms from the head and neck to the brain," said Dr Agnieszka Balkowiec, principal investigator, OHSU School of Dentistry.

She explained that head pain is signalled to the brain by the trigeminal nerve. The trigeminal nerve also conveys other types of sensation, such as touch and temperature, from numerous structures of the face, including the skin, ears, cornea, temporomandibular joints and teeth. Studies suggest that the trigeminal nerve provides the signalling pathway for pain associated with migraines, TMJ disorder, periodontal pain, dental surgical pain, trigeminal neuralgia, head and neck cancer pain, and other neuropathic and inflammatory pain conditions.

The OHSU study focused on two trigeminal nerve cell proteins: cal-

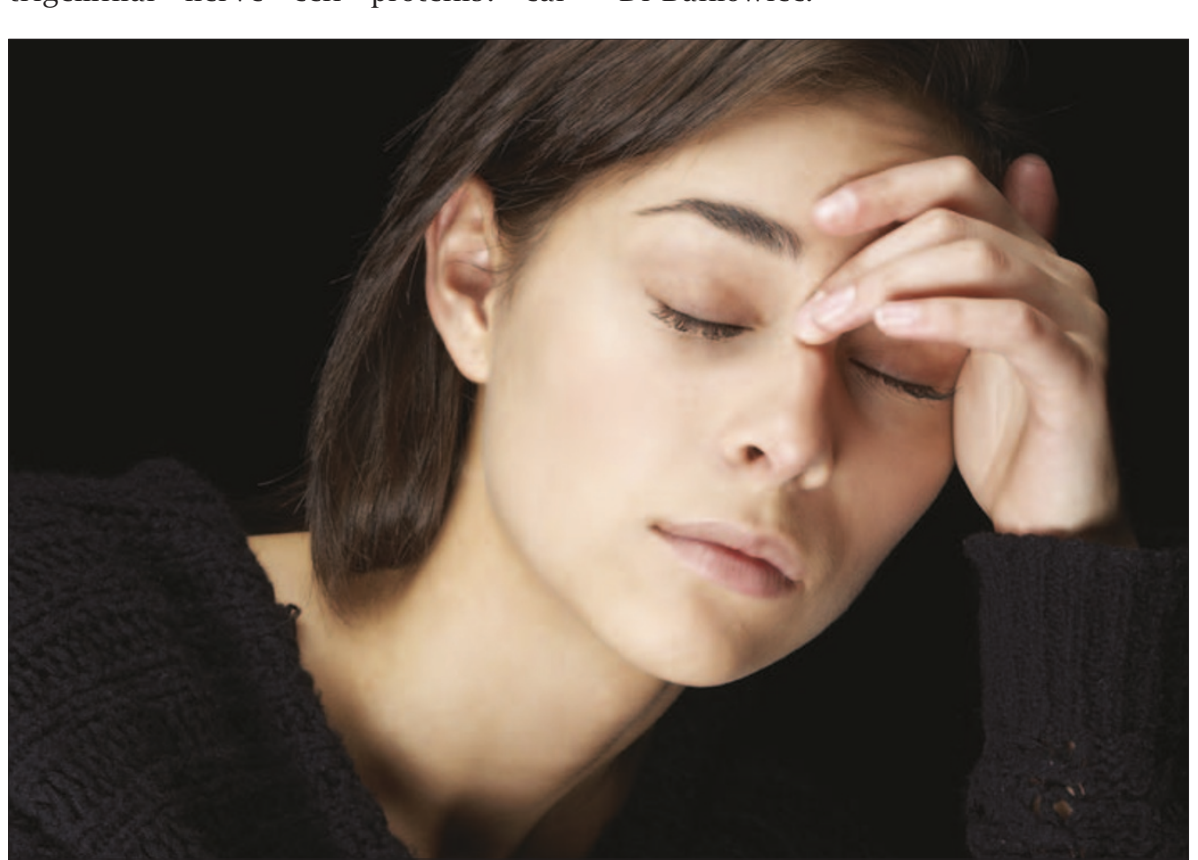

citonin gene-related peptide (CGRP), and brain-derived neurotrophic factor (BDNF). Previous studies found that during a migraine attack, the stimulation of trigeminal nerve cells releases CGRP at the peripheral end of the cells, widening blood vessels in the brain coverings called meninges.

Widening the blood vessels increases the flow of blood through the meninges and initiates an inflammatory process that likely contributes to the pain experience. Recent clinical studies show that blocking CGRP helps alleviate migraine pain.

The discovery by Dr Balkowiec and her team points to BDNF being a likely culprit behind head pain - a previously unknown finding. The OHSU team found that the stimulation of trigeminal nerve cells, as experienced during a migraine attack, leads to release of not only CGRP, but also BDNF. The study also found that BDNF is released by CGRP when trigeminal nerve cells are not stimulated. In fact, said Dr Balkowiec, CGRP's role at the central end of the trigeminal nerve cells is likely to be the facilitation of BDNF release. BDNF has previously been shown to play an important role in pain signalling from other parts of the body, but this is the first time it has been considered to be a factor in head pain.

"What we now need to better understand is how the interaction between CGRP and BDNF affects pain signalling to the brain in various disorders," said Dr Balkowiec.

\section{Correction}

In a previous issue of the $B D J(B D J$ 2006; 201: 555) we incorrectly printed that Mouth Cancer Awareness Week was run by the Mouth Cancer Foundation. Mouth Cancer Awareness Week is co-ordinated by the British Dental Health Foundation and is supported by a number of organisations, including the Mouth Cancer Foundation.

See story 'If in doubt, get checked out' on page 694.

\section{Volunteers wanted for new contract research}

The BDA is inviting dentists from England and Wales to get involved and tell the Association what they think about the changes that have occurred to NHS primary dental care services.

It is seeking volunteers for focus groups to be held during January and February 2007 at various locations. All the meetings will be held in the early evening and refreshments and a buffet supper will be provided. Everyone who puts themselves forward will get entered into a draw to win $£ 50$ worth of BDA shop products.

According to the Association, the focus groups are a major part of its programme of research which is looking into the impacts of the reform to NHS dentistry.

The purpose of the focus group will be to share experiences with each other with the aim of preparing a detailed S-W-O-T analysis (StrengthsWeaknesses-Opportunities-Threats) of the reforms.

The findings will also feed into the BDA's broader policy development work, so will directly affect the policy position being made by the organisation. It is looking for a broad, and representative, range of participants from across England and Wales.

If you are interested in helping, send an email to bdafocusgroup@bda. org by Friday 15 December stating your name, address, contact email or phone number and the focus group meeting location you prefer - London, Cardiff, Leeds, Manchester, or Birmingham. If you have further questions please contact Dan Berry (Acting Head of Secretariat) at d.berry@bda.org. 


\section{Laser dentistry and prehistoric teeth}

Laser dentistry has helped researchers discover more about the diets of our early human relatives. University of Utah scientists improved a method of testing fossil teeth, and showed that early human relatives varied their diets with the seasons 1.8 million years ago, eating leaves and fruit when available in addition to seeds, roots, tubers and perhaps grazing animals.

Study co-author and geochemist $\mathrm{Dr}$ Thure Cerling says the study of the now-extinct, ape-like species known as Paranthropus robustus is important because it "shows that the variability in human diet has been 'in the family' for a very long time. It is this variability that allows modern humans to utilise foods from all over the world."

The researchers used a laser to remove tiny samples from four 1.8-millionyear-old fossilised Paranthropus teeth, and then tested the samples to determine the ratios of two isotopes or forms of carbon.

"By analysing tooth enamel, we found that they ate lots of different things, and what they ate changed during the year," says University of Utah geology doctoral student Ben Passey, a co-author of the study in journal Science.

Passey used a laser to remove and vaporise tiny samples of enamel, which then were analysed in a mass spectrometer to determine the ratio of rare carbon13 to common carbon-12. "The previous way to sample tooth enamel was to take a dental drill with a diamond-impregnated drill bit and basically grind away at the tooth, collect the powder and then analyse that," Passey said.

In the past decade, researchers have used laser ablation to remove and analyse tooth enamel samples from the large, fossilised teeth of prehistoric horses, rhinos and elephants to determine the animals' diets.

Until now, lasers were too destructive to use on the smaller teeth of human ancestors and their relatives even those of Paranthropus, known

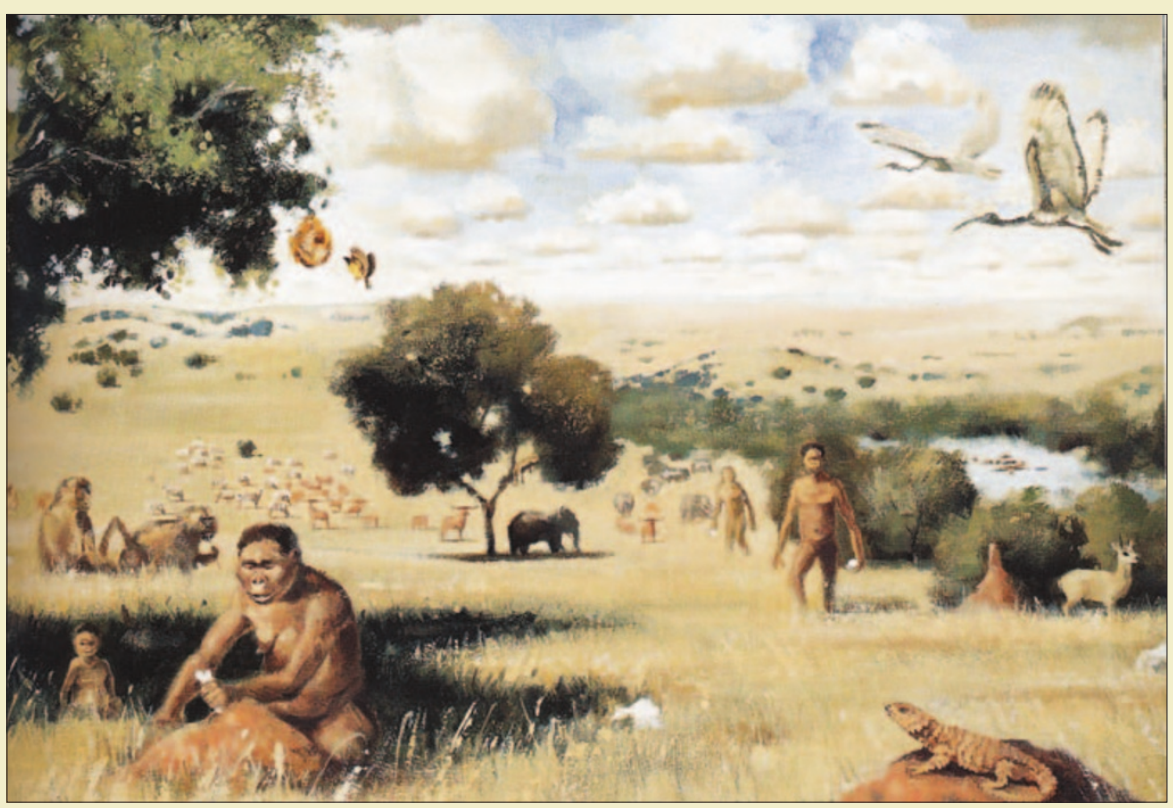

Early human relatives varied their diets

for relatively large teeth and a strong, heavy jaw.

Passey improved the laser technique by fine-tuning the method to handle very small samples like humansized teeth. He says. "If you tried the previous method on a human tooth, you would blast a hole clear through the enamel, and museum curators wouldn't like that."

The laser was used to remove samples at various points along the length of the tooth, which is marked by tiny ridges called perikymata. They run parallel to the tooth's crown and represent tooth growth, similar to tree rings. Perikymata are produced under the gums during the animal's juvenile years, when teeth are growing.

Each laser sampling vaporised enamel that formed during several months and thus represented what Paranthropus ate during that period. By taking several samples off the length of each tooth, the researchers reconstructed a few years of each creature's diet.

The research found that plants fall into two broad classes depending on the way in which they use photosynthesis to convert sunlight, water and carbon dioxide into plant matter and oxygen. Carbon isotope ratios revealed the extent to which the relatives of early humans ate so-called C3 plants, which include fruit and leaves from trees in both the forest and savanna, and C4 plants, which grow mostly on the savanna and include potato-like tubers, grasses, and seeds and roots from grasses. If the early hominids ate meat from grass-grazing animals like antelope, the C4 'signal' also showed up in their teeth.

"Hominids were taking advantage of seasonal differences in food items in a savanna environment," Dr Cerling says. "We cannot tell if they were carnivores or scavengers, but it is possible their diet included animals. We are picking up that signal."

Dr Cerling said the study "shows that our early human relatives were able to eat a varied diet and therefore were more adaptable in savanna environments than other primates who had a more restricted diet."

\section{Patient risk assessment tool}

The American Academy of Periodontology has released an online tool to help patients determine risk for periodontal diseases. The tool, which is located at www.perio.org/consumer/ 4a.html, includes a short questionnaire for patients to complete. Once submitted, a calculation based on the PreViser formula, determines whether the patient is at low, medium, or high risk for developing periodontal diseases. An individualised profile report appears, including referral recommendations.

\section{Death notice}

Eric George Searle, DFC, LDSRCS, passed away peacefully at his home at 2 Fantona Close, Church Road, Worth, West Sussex on 4th November 2006. 


\section{DIARY}

January

1st International meeting on Cold Laser Therapy in Dentistry

Date: 18 January 2007

Venue: New Orleans, USA

Tel/Fax: (888) 891-6485

\section{5th Annual North American}

Orthodontic Conference for Full

Face Orthodontic Study Group

Date: 19-21 January 2007

Venue: New Orleans, USA

Tel/Fax: (888) 891-6485

Setting up in practice

Date: 19 January 2007

Venue: BDA Lecture theatre

Tel: 02075634590

Email: events@bda.org

\section{February}

Moving to private practice conversion and beyond

Date: 23 February 2007

Venue: BDA, London

Tel: 02075634590

Email: events@bda.org

May

\section{ADI 20th Anniversary Congress}

Date: 3-5 May 2007

Venue: ICC in Birmingham

www.adi.org.uk

\section{BDA British Dental Conference} and Exhibition 2007

Date: 24-26 May 2007

Venue: Harrogate International

Centre (HIC)

Tel: 02075634590

Email: events@bda.or

June

14th Annual Congress of the Turkish Dental Association

Date: 11-17 June 2007

Venue: Lütfi Kirdar Convention Center, Istanbul, Turkey

Email: tdbkongresi.com

www.tdbkongresi.com

\section{If in doubt, get checked out} officially launched at the House of Commons last month. The campaign, which ran from 12-18 November, is coordinated by the British Dental Health Foundation and is supported by a range of organisations and companies. The tagline for the campaign was 'If in doubt, get checked out' and was launched by Chief Dental Officer for England, Barry Cockroft. Speaking ahead of the launch, Chief Executive of the British Dental Health Foundation, Dr Nigel

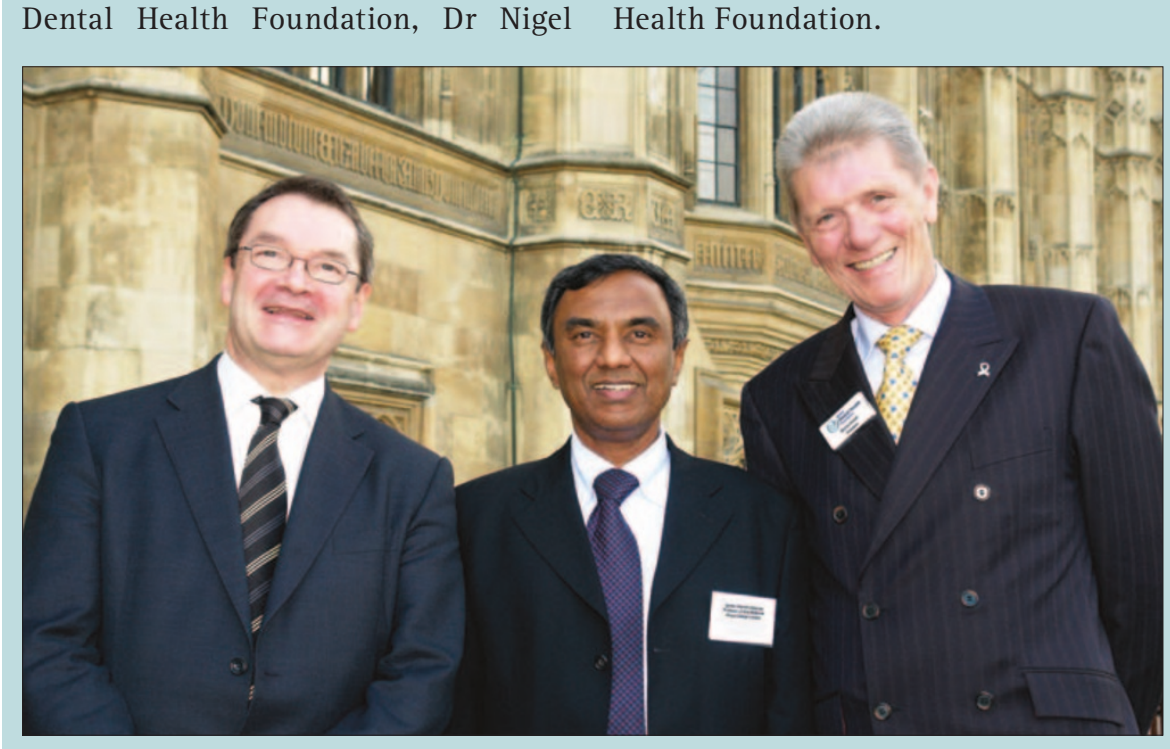

Carter commented, "Early detection of mouth cancer increases survival chances from just one in two to around nine out of ten, so increased awareness is vitally important." For more information visit www.mouthcancer. org. Pictured below from left to right, Chief Dental Officer for England Barry Cockcroft, Professor Saman Warnakulasuriya, Professor of Oral Medicine at King's College London, and Dennis Carroll, President of the British Dental Health Foundation.
Mouth Cancer Awareness Week was

\section{Children's clinic opened}

The department of paediatric dentistry of the University of Newcastle Dental Hospital \&t School, Richardson Road, Newcastle upon Tyne, was officially opened recently following the refurbishment of the clinic.

The refurbishment programme started at the end of June 2005 and all the old equipment was completely removed and replaced by brand new units in a project that cost around $£ 1.4$ million.

The new department has twenty chairs in an open clinic format and five chairs in individual surgeries. The department also has three ceiling mounted operating microscopes used for advanced restora-

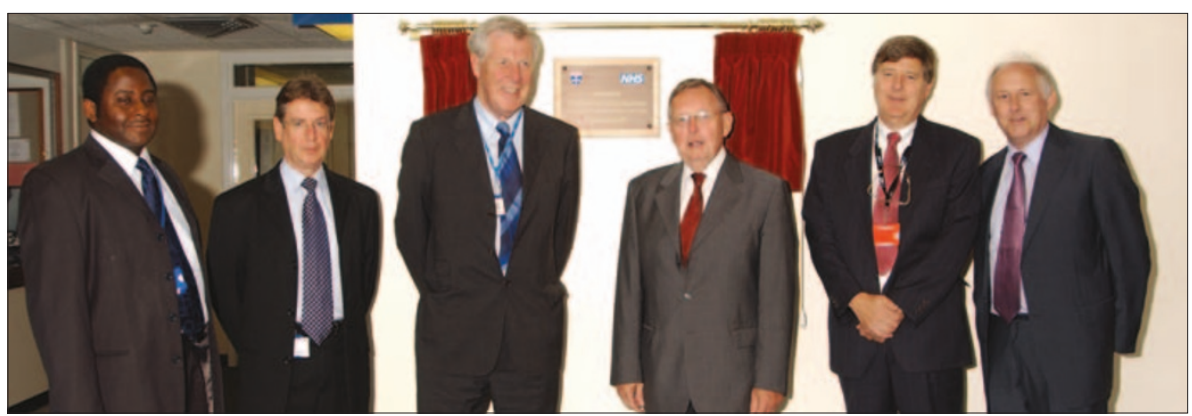

tive procedures and inhalation sedation facilities in each individual surgery as well as three in the open clinic. The newly refurbished department was officially opened by Professor JJ Murray CBE, past Dean of the Dental School and also Scientific Advisor to the $B D J$.

Pictured from left to right, Dr Ben Cole, Consultant \& Head of the Children's' department; Mr Dave Jacobs, Consultant Et Clinical Director of the Dental School, Sir Miles Irving, Chairman of the Trust Board, Prof. J J Murray, Prof. R A Seymour, current Dean and Mr L Fenwick, Chief Executive of the Newcastle upon Tyne NHS Foundation Trust. 


\section{BDA honours outstanding contributions to dentistry}

A former editor of the British Dental Journal has joined the BDA's Roll of Distinction in honour of his outstanding service to UK dentistry. Dr Mike Grace was among six individuals from the dental community who were recently honoured by the BDA at the organisation's inaugural Honours and Awards Dinner, supported by the British Dental Trade Association.

The ceremony, held at London's Langham Hotel, saw the award of three BDA Fellowships, the John Tomes Medal and two new entries to the BDA Roll of Distinction.

Dr Grace and Hon Alderman John Charlton were entered on the BDA's Roll of Distinction, honouring their outstanding service to UK dentistry. Dr Grace has been involved with training and consultancy in management both within and outside dentistry and also in undergraduate and postgraduate education, as well as vocational training and dental publishing. Hon Alderman Charlton is a director of the British Fluoridation Society and Chair of the University Hospital Birmingham NHS Foundation Trust.

BDA Fellowships, awarded in recognition of outstanding and distinguished service to the BDA and the dental profession, were conferred on $\mathrm{Dr}$ Ruby Austin MBE, Dr Janet Heath and Dr Celia Ross.

Dr Austin is a Member in General Dental Surgery of the Royal College of Surgeons, a Fellow of the Faculty of General Dental Practice and an advisor on vocational training and continuing professional development to the London Postgraduate Medical and Dental Deanery.

Dr Heath is a Member of the Faculty of General Dental Practice and a Fellow in Dental Surgery of the Royal College of Surgeons. Dr Ross, now semi-retired, is dental advisor to Buckinghamshire Primary Care Trusts and runs a domiciliary service for care home residents. All three recipients have held high office within the Association at local or national level, and have made major contributions to vocational training and professional development.

The John Tomes Medal, given to an individual in recognition of their scientific eminence and outstanding service to the dental profession, was awarded to Professor Elizabeth Treasure, Dean and Professor of Dental Public Health at Cardiff University's School of Dentistry. Professor Treasure's research activities have played an important role in the debate on water fluoridation; she is also an expert on dental workforce.

The event, hosted by BDA President $\mathrm{Dr}$ Sue Greening, was attended by 200 members of the dental community including dentists, dental care professionals and other stakeholders. Speaking after the event, Dr Greening said, "We are delighted to honour six individuals who have made tremendous contributions to the advancement of both dentistry and the BDA. The BDA is pleased to recognise the significant achievements of each of our winners."

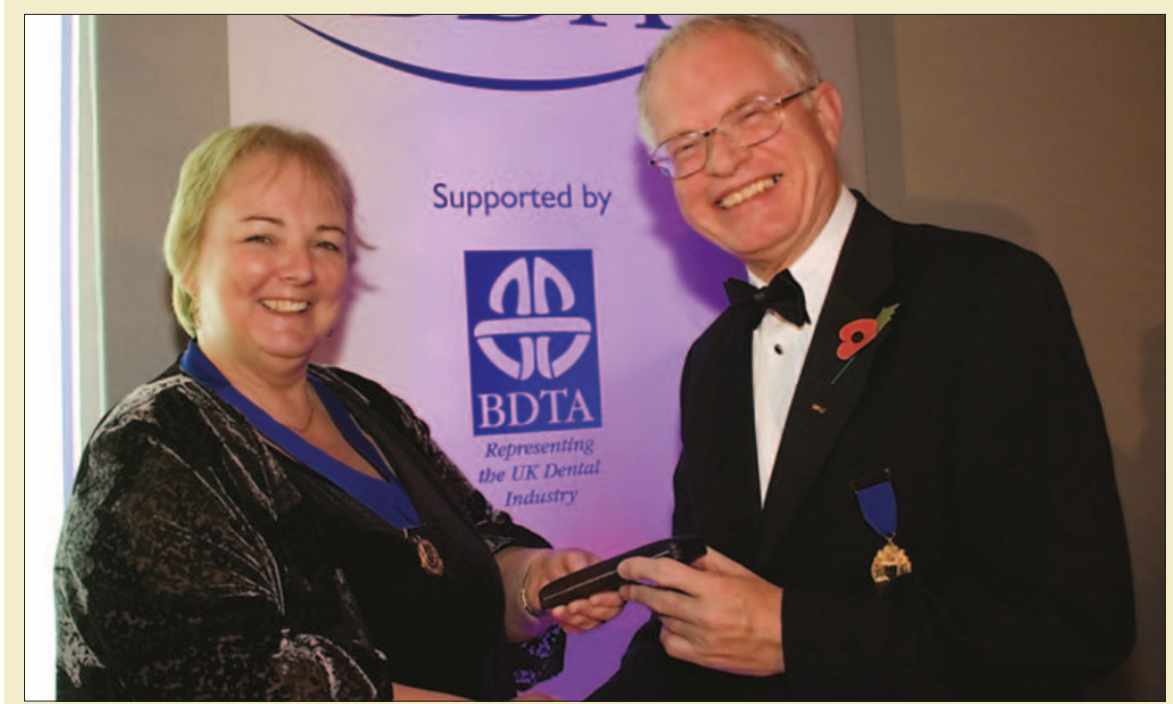

Former BDJ editor Dr Mike Grace receives his award from Susie Sanderson, Chair of the BDA's Executive Board. 